\title{
ORIGINS OF ECLOGITES BENEATH THE CENTRAL SLAVE CRATON
}

\author{
Sonja Aulbach ${ }^{1}$, W.L. Griffin ${ }^{1,2}$, Norm J. Pearson ${ }^{1}$, Suzanne Y. O'Reilly ${ }^{1}$, Kevin Kivi ${ }^{3}$ and Buddy \\ J. Doyle \\ ${ }^{1}$ GEMOC ARC National Key Centre, Macquarie University, Australia; ${ }^{2}$ CSIRO Exploration and Mining, North Ryde, \\ Australia; ${ }^{3}$ Kennecott Canada Exploration Inc., Thunder Bay, Canada; Kennecott Canada Exploration Inc., Vancouver,
} Canada

Eclogite xenoliths from Tertiary-Cretaceous Lac de Gras kimberlites include quartz-, kyanite-, diamond-, graphite-, phlogopite- and calcite-bearing types, and include a suite of opx-bearing rocks with correlated $\mathrm{CaO}$ and $\mathrm{Cr}_{2} \mathrm{O}_{3}$ contents (pyroxenites), suggesting a multiplicity of origins. Eclogites were studied in detail petrographically and for major and trace-element and isotopic composition in order to elucidate questions such as when and where they formed, their spatial relationship within the lithospheric mantle and their relationship to tectonic events evident in the overlying crust. We will focus here on the origin of three suites of eclogites, based on the Ca-content of garnets (Pearson et al., 1999; Griffin et al., 1999): a high-Ca suite, including kyanite ( \pm diamond/graphite/rutile) bearing eclogites and a low-Ca suite ( \pm quartz/rutile). The low$\mathrm{Ca}$ suite is subdivided into high-Mg and low-Mg types.

\section{MAJOR AND TRACE-ELEMENTS, HAFNIUM ISOTOPE DATA}

Whole-rock analyses sometimes reflect interaction of xenoliths with the host kimberlite (e.g., Taylor and Neal, 1989). Therefore, pre-entrainment whole rock eclogite compositions were reconstructed from their constituents (garnet, clinopyroxene \pm rutile) using mineral modes and major and trace-element contents, obtained with electron microprobe and laser ablation ICPMS, respectively (Table 1). Rutile modes were calculated assuming that whole rocks have no negative Ti anomalies relative to NMORB. For eclogite samples too small to determine meaningful modes, a garnet proportion of 0.65 and cpx proportion of 0.35 are assumed, reflecting the average modes of samples for which modal information was available. Calculated bulk compositions of highly incompatible elements are subject to large errors mainly because of modal uncertainties. Hf isotope compositions were obtained in situ in rutile using a $\mathrm{Nu}$ Instruments " $\mathrm{Nu}$ Plasma" multicollector attached to a LUV266 laser microprobe. Assuming that the assemblages were in isotopic equilibrium, isotope data were combined with the whole-rock data and are given in Table 1. Garnet major element compositions are shown in Fig. 1. The temperature distribution for the three eclogite suites is shown in Fig. 2.

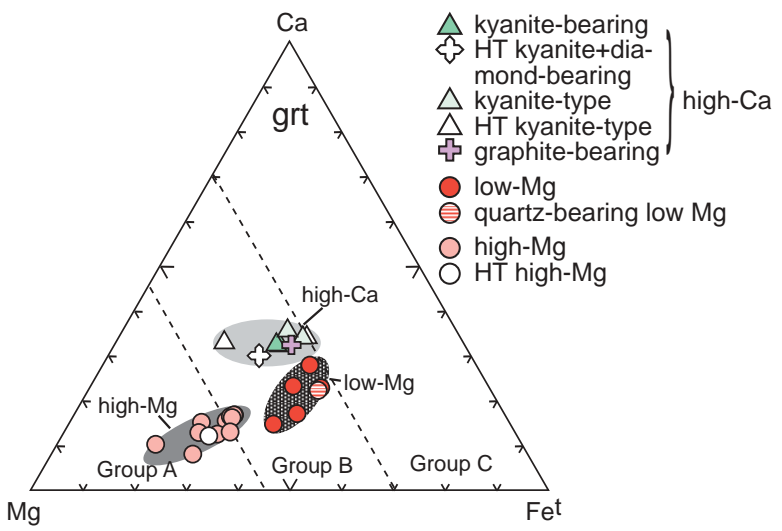

Figure 1 Molar $\mathrm{Mg}$-Ca-Fe in garnet. Based on garnet composition, eclogites have been divided into a high-Ca, a low-Mg and a high-Mg suite. High-temperature (HT) samples $\quad(\mathrm{T} \geq$ $1150^{\circ} \mathrm{C}$; all others: $\mathrm{T} \leq 1050^{\circ} \mathrm{C}$ ) are shown separately. Fields for Group A, B and C ecogites from Shervais et al. (1988)

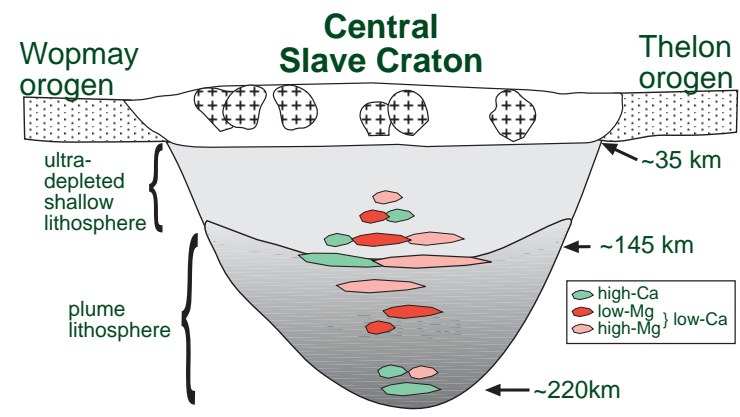

Figure 2 Sketch (after Griffin et al., 1999) showing relative distribution of high-Ca, low-Mg and high-Mg eclogites in the lithosphere beneath the central Slave Craton $\left(\mathrm{T}_{\mathrm{Krogh}}\right.$ (Krogh, 1988) calculated at a nominal pressure of $40 \mathrm{kbar}$ )

\section{ORIGINS OF THE LOW-CA AND HIGH- CA SUITES}

Within the low-Ca eclogite suite, most high-Mg garnets can be assigned to group A eclogites. Low-Mg and high-Ca garnets plot in the field of group B eclogites in the classification of Shervais et al. (1988) (Fig. 1). Most eclogites show small positive $\mathrm{Sr}$ anomalies, and many 
have small or marked positive Eu-anomalies suggesting plagioclase accumulation in the protolith. High-Mg eclogites and high-Ca eclogites are enriched in MREE relative to LREE and HREE. This may indicate that cpx accumulation was also important in their formation. All garnets lie on a negative correlation of $\mathrm{Mg}$-number with $\mathrm{Yb}\left(\mathrm{r}^{2}=0.81, \mathrm{n}=17\right)$ (Fig. 3), which can be interpreted as an olivine fractionation trend. If eclogites from Lac de Gras have a high-pressure magmatic origin, high-Ca eclogites could have formed from cumulates of hyperaluminous cpx that later exsolved kyanite and garnet (Smyth et al., 1989), whereas formation of the low-Ca eclogites included variable later accumulation of low-Al cpx. In this scenario, the eclogites would acquire their $\mathrm{Pb}, \mathrm{Sr}$ and $\mathrm{Eu}$ anomalies through interaction in the mantle with slab-derived materials. In the following, we explore the possibility that both low$\mathrm{Ca}$ and high-Ca eclogites have a crustal origin. If so, they are the products of several processes, such as fractionation and accumulation during formation of the protoliths, seafloor alteration, dehydration during subduction and possibly melting and metasomatism.

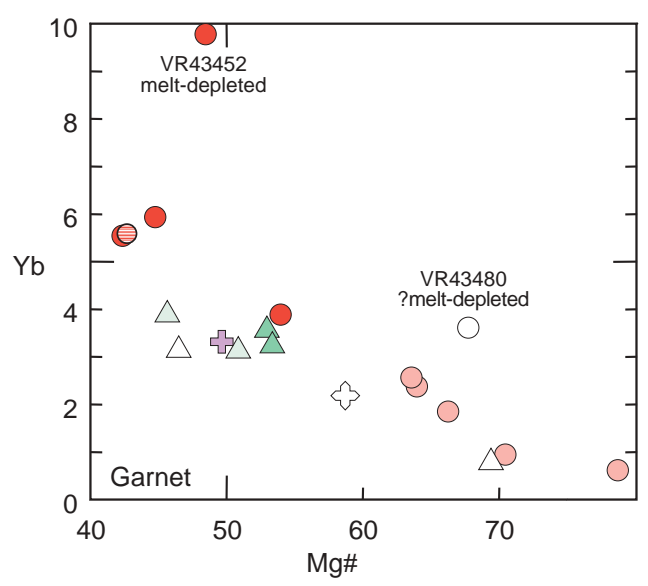

Figure $3 \mathrm{Mg}$-number versus $\mathrm{Yb}$ abundance (ppm) in garnet. Symbols as in Figure 1

\section{Table 1: Compositions of selected} reconstructed whole rocks

\begin{tabular}{|c|c|c|c|c|}
\hline & vr19674 & vr19677 & vr43452 & $\operatorname{vr} 43469$ \\
\hline Access. & rut & rut & rut & rut \\
\hline \multirow[t]{2}{*}{ Suite } & low-Ca/ & low-Ca/ & low-Ca/ & low-Ca/ \\
\hline & low-Mg & high-Mg & low-Mg & low-Mg \\
\hline $\mathrm{SiO}_{2}[\mathrm{wt} \%]$ & ] 44.5 & 45.3 & 47.6 & 44.8 \\
\hline $\mathrm{TiO}_{2}$ & 0.8 & 0.9 & 0.4 & 0.7 \\
\hline $\mathrm{Al}_{2} \mathrm{O}_{3}$ & 16.4 & 16.2 & 14.9 & 15.9 \\
\hline $\mathrm{FeO}$ & 15.1 & 10.9 & 13.1 & 13.6 \\
\hline $\mathrm{MnO}$ & 0.31 & 0.24 & 0.21 & 0.26 \\
\hline $\mathrm{MgO}$ & 9.2 & 14.1 & 10.3 & 9.5 \\
\hline $\mathrm{CaO}$ & 11.1 & 10.6 & 10.7 & 13.2 \\
\hline $\mathrm{Na}_{2} \mathrm{O}$ & 1.7 & 1.2 & 2.6 & 1.6 \\
\hline
\end{tabular}

\begin{tabular}{|c|c|c|c|c|}
\hline Total & 99.0 & 99.3 & 99.9 & 99.6 \\
\hline \multicolumn{5}{|c|}{$\mathrm{T}_{\text {Krogh }}\left[{ }^{\circ} \mathrm{C}\right]$} \\
\hline$@ 40 \mathrm{kbar}$ & 870 & 940 & 1030 & 1030 \\
\hline $\mathrm{P}$ [ppm] & 190 & 150 & 150 & 38 \\
\hline $\mathrm{Rb}$ & 0.12 & 0.17 & 0.03 & 0.04 \\
\hline $\mathrm{Sr}$ & 68 & 86 & 52 & 34 \\
\hline Y & 26 & 15 & 32 & 28 \\
\hline $\mathrm{Zr}$ & 30 & 21 & 11 & 15 \\
\hline $\mathrm{Nb}$ & 3.6 & 0.35 & 0.055 & 0.18 \\
\hline $\mathrm{Ba}$ & 1.1 & 0.75 & 0.21 & 0.09 \\
\hline $\mathrm{La}$ & 1.2 & 1.1 & 0.17 & 0.52 \\
\hline $\mathrm{Ce}$ & 2.7 & 4.7 & 0.7 & 1.5 \\
\hline $\operatorname{Pr}$ & 0.43 & 0.98 & 0.13 & 0.26 \\
\hline $\mathrm{Nd}$ & 2.2 & 5.8 & 0.77 & 1.7 \\
\hline $\mathrm{Sm}$ & 1.2 & 1.9 & 0.43 & 1.1 \\
\hline $\mathrm{Eu}$ & 0.56 & 0.80 & 0.22 & 0.53 \\
\hline Dy & 4.1 & 2.6 & 3.8 & 4.4 \\
\hline $\mathrm{Yb}$ & 3.6 & 1.6 & 4.9 & 3.6 \\
\hline $\mathrm{Lu}$ & 0.60 & 0.27 & 0.78 & 0.59 \\
\hline $\mathrm{Pb}$ & 0.50 & 0.44 & 0.14 & 0.17 \\
\hline Th & 0.25 & 0.07 & $<\mathrm{dl}$ & 0.01 \\
\hline $\mathrm{U}$ & 0.02 & 0.03 & $<\mathrm{dl}$ & 0.01 \\
\hline${ }^{176} \mathrm{Hf} /{ }^{177} \mathrm{Hf}$ & 0.28303 & 0.28368 & 0.28253 & 0.28567 \\
\hline \multirow[t]{2}{*}{$2 \mathrm{se}$} & 0.00009 & 0.00082 & 0.00056 & 0.00010 \\
\hline & vr50909 & yk1943 & yk1946 & yk1949 \\
\hline Access. & rut,kya & rut, qz & rut & rut \\
\hline Suite & high-Ca & $\begin{array}{l}\text { low-Ca/ } \\
\text { low-Mg }\end{array}$ & $\begin{array}{l}\text { low-Ca/ } \\
\text { high-Mg }\end{array}$ & $\begin{array}{l}\text { low-Ca/ } \\
\text { high-Mg }\end{array}$ \\
\hline \multicolumn{2}{|c|}{$\mathrm{SiO}_{2}[\mathrm{wt} \%] 44.8$} & 45.6 & 46.1 & 45.2 \\
\hline $\mathrm{TiO}_{2}$ & 1.2 & 0.9 & 0.8 & 0.3 \\
\hline $\mathrm{Al}_{2} \mathrm{O}_{3}$ & 19.7 & 15.2 & 16.1 & 18.5 \\
\hline $\mathrm{FeO}$ & 10.4 & 14.2 & 10.3 & 11.5 \\
\hline $\mathrm{MnO}$ & 0.16 & 0.27 & 0.18 & 0.24 \\
\hline $\mathrm{MgO}$ & 8.6 & 9.8 & 14.7 & 13.9 \\
\hline $\mathrm{CaO}$ & 11.8 & 12.1 & 9.9 & 8.4 \\
\hline $\mathrm{Na}_{2} \mathrm{O}$ & 2.7 & 1.9 & 1.5 & 1.5 \\
\hline Total & 99.4 & 99.9 & 99.6 & 99.4 \\
\hline \multicolumn{5}{|c|}{$\mathrm{T}_{\mathrm{Krogh}}\left[{ }^{\circ} \mathrm{C}\right]$} \\
\hline @ 40 kbar & 910 & 870 & 920 & 790 \\
\hline $\mathrm{P}[\mathrm{ppm}]$ & 250 & 170 & 150 & 100 \\
\hline $\mathrm{Rb}$ & 0.07 & 0.0018 & 0.22 & 0.14 \\
\hline $\mathrm{Sr}$ & 42 & 120 & 110 & 46 \\
\hline Y & 22 & 25 & 12 & 10 \\
\hline $\mathrm{Zr}$ & 57 & 48 & 48 & 14 \\
\hline $\mathrm{Nb}$ & 1.3 & 8.2 & 0.8 & 0.28 \\
\hline $\mathrm{Ba}$ & 0.33 & 0.19 & 0.29 & 0.41 \\
\hline $\mathrm{La}$ & 0.055 & 3.4 & 1.0 & 0.88 \\
\hline $\mathrm{Ce}$ & 0.3 & 8.5 & 3.8 & 2.1 \\
\hline $\operatorname{Pr}$ & 0.19 & 1.3 & 0.79 & 0.32 \\
\hline $\mathrm{Nd}$ & 0.19 & 1.3 & 0.79 & 0.32 \\
\hline $\mathrm{Sm}$ & 2.1 & 2.1 & 1.8 & 0.58 \\
\hline $\mathrm{Eu}$ & 1.07 & 0.78 & 0.73 & 0.25 \\
\hline Dy & 4.1 & 4.2 & 2.2 & 1.4 \\
\hline $\mathrm{Yb}$ & 2.1 & 3.2 & 1.2 & 1.8 \\
\hline $\mathrm{Lu}$ & 0.30 & 0.53 & 0.18 & 0.31 \\
\hline $\mathrm{Pb}$ & 0.13 & 0.50 & 0.29 & 0.19 \\
\hline Th & 0.021 & 0.13 & 0.059 & 0.033 \\
\hline $\mathrm{U}$ & 0.024 & 0.028 & 0.0253 & 0.012 \\
\hline${ }^{176} \mathrm{Hf} /{ }^{177} \mathrm{Hf}$ & 0.28164 & 0.28228 & 0.28156 & 0.28453 \\
\hline $2 \mathrm{se}$ & 0.00024 & 0.00008 & 0.00026 & 0.00342 \\
\hline
\end{tabular}




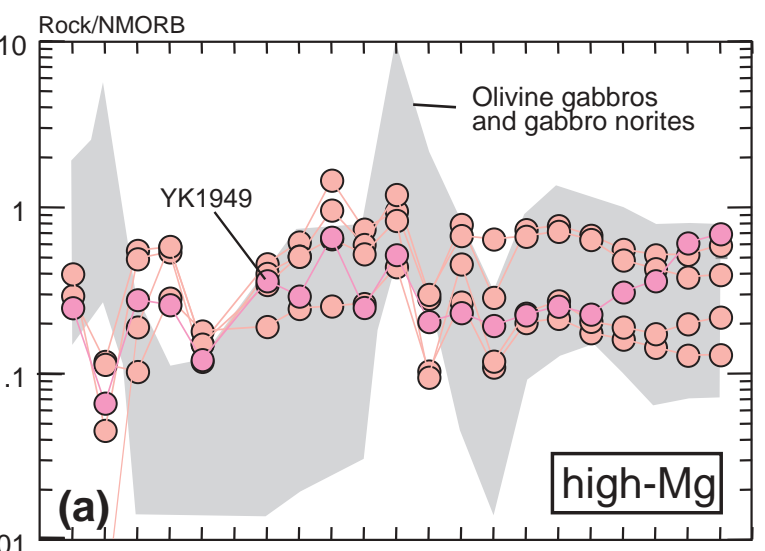

01 RbBaTh U Nb K LaCePbPr Sr P NdZrSmEu Ti Dy Y YbLu
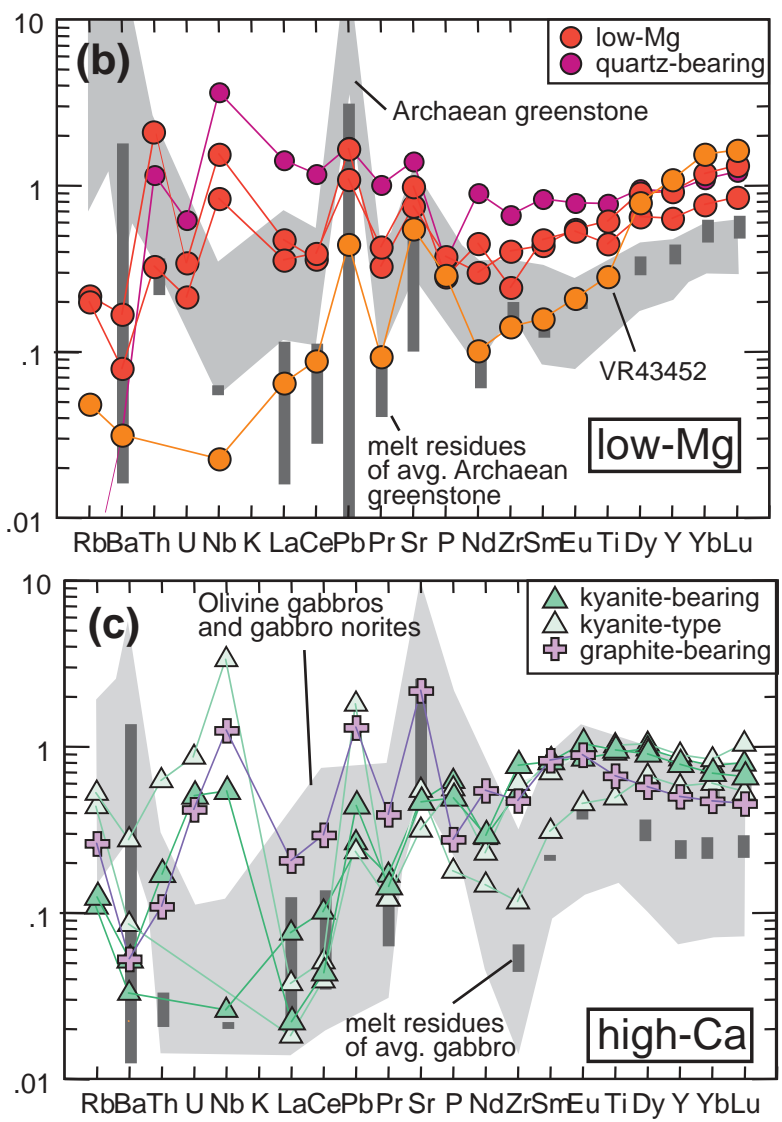

Figure 4 NMORB normalised trace-element abundances of reconstructed eclogites. High-temperature rocks have been left out for clarity. Shown for comparison are a range of olivine gabbros and gabbro norites (Benoit et al., 1996) and Archaean greenstones (Polat et al., 2002). Bars represent the range of residues (5-30\% partial melt extraction) of eclogitised average gabbros and greenstones, using mineraltonalite partition coefficients of Barth et al. (2002) and Foley et al. (2000). NMORB of Sun and McDonough (1989)

\section{PROTOLITH(s)}

Eclogites from Lac de Gras have major-element contents broadly similar to gabbroic rocks in ophiolites, but trend towards higher $\mathrm{FeO}$ and $\mathrm{MnO}$. More or less pronounced positive $\mathrm{Eu}$ and $\mathrm{Sr}$ anomalies, and in some instances negative $\mathrm{Zr}$ anomalies and low HREE abundances, also point to a gabbroic protolith. High-Mg eclogites (except YK1949) have relatively flat HREE patterns similar to cumulates in the Oman ophiolite, whereas low-Mg eclogites have fractionated HREE resembling some Archaean greenstones (Fig. 4). If these eclogites are crustally derived, discrepancies between the abundances of highly incompatible elements in potential precursors and in samples from this study may be partially due to post-formation modification (see below). The negative trend of $\mathrm{Mg \#}$ versus $\mathrm{Yb}$ (Fig. 3) may be ascribed to olivine fractionation in the precursor basalt and was inherited by garnet and cpx during eclogitisation.

\section{SeAwATER ALteration}

Almost all eclogites from Lac de Gras have small positive $\mathrm{Pb}$ anomalies. This could be explained by seawater alteration, as $\mathrm{Pb}$ is one of the elements most affected by this process (Jochum and Verma, 1996). Enhanced $\mathrm{FeO}$ and $\mathrm{MnO}$ contents relative to assumed gabbroic precursors could also be related to interaction with seawater (Jacob et al., 1994).

\section{DEHYDRATION}

Lac de Gras eclogites have low $\mathrm{K}_{2} \mathrm{O} / \mathrm{Th}, \mathrm{Ba} / \mathrm{Th}$, $\mathrm{K}_{2} \mathrm{O} / \mathrm{Nb}$ and $\mathrm{Ba} / \mathrm{Nb}$ relative to gabbros, altered oceanic crust and Archaean greenstones. This may reflect the loss of $\mathrm{Pb}, \mathrm{K}$ and $\mathrm{Ba}$, but lesser amounts of $\mathrm{Th}$ and $\mathrm{Nb}$ during dehydration as $\mathrm{Nb}$ and $\mathrm{Th}$ are not strongly fluidmobile, whereas $\mathrm{Pb}$ and the alkalis are (Becker et al., 2000).

\section{MeLTING}

Residues calculated from hypothetical eclogitised equivalents of gabbroic protoliths were compared to reconstructed eclogitic whole rocks. Of the low-Ca eclogites, only sample VR43452 is depleted enough in LREE to represent a melting residue (Fig. 3b). Hence, melting after subduction was probably not important in establishing the final trace-element budget of most lowCa eclogites. By contrast, the very low LREE/HREE in most high-Ca eclogites points to the loss of partial melt after eclogitisation (i.e., after the stabilisation of garnet) (Fig. 3c), which may have been aided by their high content in fusible elements (Fe, $\mathrm{Ca}, \mathrm{Na}$ ). Sample VR43452 plots off the "olivine fractionation trend" in 
Fig. 2, possibly because partial melting of this rock increased both the $\mathrm{Yb}$ and $\mathrm{Mg}$ contents, although this is not observed for the presumably melt-depleted high-Ca eclogites.

\section{Metasomatism}

Four of five high-Mg are lightly LREE-depleted but have small negative slopes between $\mathrm{Nd}$ and $\mathrm{Lu}$. This could be explained by an early stage of melt metasomatism (e.g., Navon and Stolper, 1987) but may simply reflect cpx accumulation in the protolith. The smooth LREE-enrichment of the quartz-bearing low-Mg eclogite is not accompanied by a Eu anomaly and therefore not due to plagioclase accumulation in the protolith. It may have resulted from later stages of metasomatic re-enrichment after emplacement in the lithosphere or may have been inherited from the protolith source (e.g., E-type MORB mantle).

\section{NB-RICH SAMPLES}

Three of the low-Mg eclogites have high $\mathrm{Nb}$ abundances. In these samples, calculated rutile modes may have been overestimated leading to spuriously high $\mathrm{Nb}$ abundances. Also, where rutile was not exposed in the thin sections an average rutile composition was used in the reconstruction, and $\mathrm{Nb}$ abundances in this average rutile may be overestimated.

\section{HIGH-CA ECLOGITES AND THEIR CARBON SOURCE}

High-Ca eclogites may contain accessory diamond and graphite, and there is a marked overlap between the composition of garnet and, to a lesser extent, cpx in high-Ca eclogites and one particular inclusion suite recorded in diamond (Davies et al., 1999). No carbon in low-Ca eclogites or inclusions in diamond similar to the low-Ca eclogites have been observed. Thus, there appears to be a link between high-Ca eclogites, derived from depths giving about $880^{\circ}$ and $1210^{\circ} \mathrm{C}$, and the occurrence of carbon both as graphite and as diamond. Like the eclogites, the associated carbon may be crustally derived and subducted, or mantle-derived.

In a crustal origin scenario, the occurrence of carbon in high-Ca eclogites and its absence in low-Ca eclogites could be related to the situation of the protolith in the oceanic lithosphere. High-Ca eclogites have compositions comparable to gabbroic cumulates in ophiolites, which are interpreted as former oceanic crust. Positive $\mathrm{Pb}$-anomalies may indicate that interaction with seawater has occurred. Perhaps the deep hotter oceanic crust is affected by a style of seawater alteration during which carbon is dumped in the form of carbonate whereas it remains in solution in shallower parts. In this case, the graphite and diamonds could be the remnants of decarbonation during subduction. Alternatively, carbon was added during processes subsequent to subduction and emplacement of the eclogites in the mantle. In this case, both lowand high-temperature high-Ca eclogites would have been affected by random localised interaction with CHO-rich fluids. The origin of the apparent association of carbon and high-Ca eclogites cannot be resolved with the current data; acquisition of $\mathrm{Hf}-\mathrm{Nd}-\mathrm{Sr}$ isotope data in the near future may shed some light on this issue.

\section{HF ISOTOPE CONSTRAINTS}

Hf isotope ratios obtained in situ from rutile were combined with reconstructed whole-rock Lu/Hf, assuming that the assemblages were in isotopic equilibrium (see Table 1). Lu/Hf and ${ }^{176} \mathrm{Hf} /{ }^{177} \mathrm{Hf}$ are correlated for seven of eight eclogitic samples (Fig. 5). Sample VR43452 has low ${ }^{176} \mathrm{Hf} /{ }^{177} \mathrm{Hf}$ relative to its $\mathrm{Lu} / \mathrm{Hf}$ and plots off the trend. This sample has traceelement abundances suggesting it has lost a partial melt. The low ${ }^{176} \mathrm{Hf} /{ }^{177} \mathrm{Hf}$ relative to Lu/Hf may indicate that the melt loss and associated increase in Lu/Hf occurred significantly later than its formation, which would not allow as much radiogenic Hf to be accrued. By contrast, kyanite-bearing eclogite (VR50909) also appears to have lost a partial melt, yet plots on the trend, perhaps due to melt loss very soon after its formation.

The linear relationship between $\mathrm{Lu} / \mathrm{Hf}$ and $\mathrm{Hf}$ isotopic compositions may represent an isochron, giving $1.91 \pm 0.36 \mathrm{Ga}(\mathrm{MSWD}=0.78)$. This corresponds to the age of eastward-oriented subduction to the west of the Slave Craton (Gandhi et al., 2001). In this case, the fact that three high-Mg, three low-Mg eclogites and one high-Ca eclogite lie on this trend would be compatible with a genetic relationship between these eclogite suites. However, the subchondritic initial Hf isotopic composition $(0.28062 \pm 0.00040)$ differs vastly from the expected $\mathrm{Hf}$ isotopic composition of a MORB source at 1.9 Ga. Chondritic materials would have last had such a low ${ }^{176} \mathrm{Hf} /{ }^{177} \mathrm{Hf} 3.2 \pm 0.3 \mathrm{Ga}$ ago. Therefore, the correlation probably represents either a mixing line, in which case the isochron age would be a maximum age, or a resetting age, in which case the isochron age would be a minimum age. Ancient subcontinental lithospheric mantle (SCLM), such as that expected beneath the Slave Craton, evolves at low Lu/Hf (Griffin et al., 2000). Eclogites may have isotopically equilibrated with the SCLM during a mantle-wide event 1.9 Ga ago. 


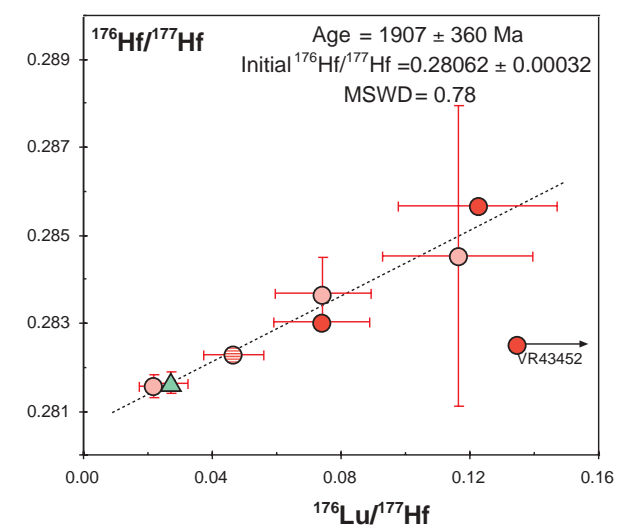

Figure $5 \mathrm{Lu}-\mathrm{Hf}$ isochron diagram. Symbols as in Fig. 1. ${ }^{176} \mathrm{Lu} /{ }^{177} \mathrm{Hf}$ was calculated from whole-rock Lu/Hf using relative isotope abundances and $20 \%$ errors were assumed. Errors in ${ }^{176} \mathrm{Hf} /{ }^{177} \mathrm{Hf}$ are two standard errors

\section{REFERENCES}

Barth, M.G., Foley, S.F., Horn, I., 2002. Partial melting in Archean subduction zones: constraints from experimentally determined trace element partition coefficients between eclogitic minerals and tonalitic melts under upper mantle conditions. Precamb. Res. $113,323-340$.

Becker, H., Jochum, K.P., Carlson, R.W., 2000. Trace element fractionation during dehydration of eclogites from high-pressure terranes and the implications for element fluxes in subduction zones. Chem. Geol. 163, 65-99.

Benoit, M., Polvé, M., Ceuleneer, G., 1996. Trace element and isotopic characterisation of mafic cumulates in a fossil mantle diapir (Oman ophiolite). Chem. Geol. 134, 199-214.

Davies, R.M. Griffin, W.L., Pearson, N.J., Andrew, A.S., Doyle, B.J., O'Reilly, S.Y., 1999. Diamonds from the deep: Pipe DO-27, Slave Craton, Canada. In: Gurney, J.J., Gurney, J.L., Pascoe, M.D., Richardson, S.H. (Eds.), Proc. 7th Int. Kimb. Conf. Red Roof Design cc, Cape Town, pp. 148-155.

Foley, S.F., Barth, M.G., Jenner, G.A., 2000. Rutile/melt partition coefficients for trace elements and an assessment of the influence of rutile on the trace element characteristics of subduction zone magmas. Geochim. Cosmochim. Acta 64, 933-938.

Gandhi, S.S., Mortensen, J.K., Prasad, N., van Breemen, O., 2001. Magmatic evolution of the southern Great Bear continental arc, northwestern Candian Shield: geochronological constraints. Can. J. Earth Sci. 38, 767-785.

Griffin, W.L. Doyle, B.J., Ryan, C.G ., Pearson, N.J., O'Reilly, S.Y., Davies, R., Kivi, K., van Achterbergh, E., Natapov, L.M., 1999. Layered Mantle Lithosphere in the Lac de Gras Area, Slave Craton: Composition, Structure and Origin. J Petrol, 40: 705-727.
Griffin, W.L., Pearson, N.J., Belousova, E., Jackson, S.E., van Achterbergh, E., O'Reilly, S.Y., Shee, S.R.., 2000. The Hf isotope composition of cratonic mantle: LAMMC-ICPMS analysis of zircon megacrysts in kimberlites. Geochim. Cosmochim. Acta 64, 133-147.

Jacob, D., Jagoutz, E., Lowry, D., Mattey, D., Kudrjavtseva, G., 1994. Diamondiferous Eclogites From Siberia Remnants of Archean Oceanic- Crust. Geochim. Cosmochim. Acta. 58, 5191-5207.

Jochum, K.P., Verma, S.P., 1996. Extreme enrichment of Sb, $\mathrm{Tl}$ and other trace elements in altered MORB. Chem. Geol. 130, 289-299.

Krogh, E., 1988. The garnet-clinopyroxene iron-magnesium geothermometer - a reinterpretation of existing experimental data. Contrib. Mineral. Petrol. 99, 44-48.

Navon, O., Stolper, E., 1987. Geochemical consequences of melt percolation: the upper mantle as a chromatographic column. J. Geol. 95, 285-307.

Pearson, N.J., Griffin, W.L., Doyle, B.J., O'Reilly, S.Y., van Achterbergh, E., Kivi, K., 1999. Xenoliths from kimberlite pipes of the Lac de Gras area, Slave Craton, Canada. In: Gurney, J.J., Gurney, J.L., Pascoe, M.D., Richardson, S.H. (Eds.), Proc. 7th Int. Kimb. Conf., Red Roof Design cc, Cape Town, pp. 644-658.

Polat, A., Hofmann, A.W., Rosing, M.T., 2002. Boninite-like volcanic rocks in the 3.7-3.8 Ga Isua greenstone belt, West Greenland: geochemical evidence for intraoceanic subduction zone processes in the early Earth. Chem. Geol. 184, 231-254.

Shervais, J.W., Taylor, L. A., Lugmair, G. W., Clayton, R. N., Mayeda, T. K., Korotev, R. L., 1988. Early Proterozoic oceanic crust and the evolution of subcontinental mantle: eclogites and related rocks from southern Africa. GSA Bull. 100, 411-423.

Smyth, J.R., Caporuscio, F.A., McCormick, T.C., 1989. Mantle eclogites: evidence of igneous fractionation in the mantle. Earth Planet. Sci. Lett. 93, 133-141.

Sun, S.-S., McDonough, W.F., 1989. Chemical and isotopic systematics of oceanic basalts: implications for mantle composition and processes. In: Saunders, A.D., Norry, M.J. (Eds.), Magmatism in the ocean basins. Geol. Soc. Spec. Publ. 42, 315-345.

Taylor, L.A., Neal, C.R., 1989. Eclogites with oceanic crustal and mantle signatures from the Bellsbank kimberlite, South Africa, Part I: Mineralogy, petrography, and whole rock chemistry. J. Geol. 97, 551-567.

Contact: S. Aulbach, GEMOC, Macquarie University 2109,

Australia (www.es.mq.edu.au/GEMOC/), E-mail

saulb001@laurel.ocs.mq.edu.au 